\title{
Pemberdayaan Karang Taruna Desa Bunga-Bunga dalam Menangkal Hoaks terkait COVID-19
}

\author{
Empowering the Bunga-Bunga Village Youth Organization in Warding off Hoaxes related to \\ COVID-19
}

Kurnia Harli*
Heriyati
Eva Yuliani
Masyita Haerianti
Muhammad Irwan
Irfan
Department of Nursing, Universitas
Sulawesi Barat, Majene, West
Sulawesi, Indonesia
email: harlikurnia21@gmail.com
Kata Kunci
COVID-19
Hoaks
Komunikasi
Keywords:
COVID-19
Hoax
Communication

\begin{abstract}
Abstrak
Selama pandemi COVID-19, penyebaran hoaks terkait COVID-19 dengan judul yang provokatif tidak terkendali. Karang taruna sebagai wadah pemuda untuk mengembangkan diri, menumbuhkan kesadaran dan tanggung jawab sosial dari, untuk, dan oleh pemuda diharapkan mampu mengatasi permasalahan sosial yang dihadapi dengan berperan aktif dalam meningkatkan kesadaran dan kewaspadaan masyarakat, khususnya terkait hoaks COVID-19. Oleh karena itu, melalui kegiatan pemberdayaan ini, Karang Taruna Desa Bunga-Bunga sebagai konsumen aktif internet diharapkan dapat meningkatkan kemampuan berfikir kritis dalam menyaring dan menginterpretasikan informasi yang diterima dari internet serta mengedukasi sesama untuk meminimalisir adanya informasi hoaks terkait COVID-19 di masyarakat. Metode kegiatan ini adalah ceramah dan diskusi tentang komunikasi efektif, hoaks dan COVID-19. Pengetahuan peserta dinilai dengan pre-test dan post-test. Pengetahuan peserta tentang topik hoaks dan COVID-19 meningkat sementara topik komunikasi menurun, sehingga dapat disimpulkan bahwa peserta mampu menafsirkan informasi hoaks terkait COVID-19.
\end{abstract}

\begin{abstract}
During this pandemic, the spreading of hoaxes related to COVID-19 with provocative titles is out of control. Youth organizations as a forum for youth to develop themselves, grow awareness and social responsibility from, for, and by youths were expected to overcome social problems faced by taking an active role in increasing public awareness and vigilance, primarily related to the COVID-19 hoax. Therefore, through this empowerment activity, Desa Bunga-Bunga youth organizations as active internet consumers were expected to increase their ability to think critically in filtering and interpreting information received from the internet and educate others to minimize the existence of hoax-related to COVID-19 in the community. The method of this activity was lecture and discussion of effective communication, hoax, and COVID-19. The participants' knowledge was assessed by pre-test and post-test. The participants' understanding of hoax and COVID-19 increased while the communication topic decreased. In conclusion, the participants could sort out hoaxes related to COVID-19.
\end{abstract}

() 2022 Kurnia Harli, Heriyati, Eva Yuliani, Masyita Haerianti, Muhammad Irwan, Irfan. Published by Institute for Research and Community Services Universitas Muhammadiyah Palangkaraya. This is Open Access article under the CC-BY-SA License (http://creativecommons.org/licenses/by-sa/4.0/). DOI: https://doi.org/10.33084/pengabdianmu.v7i1.2250

\section{PENDAHULUAN}

Angka pengguna internet dan media sosial di Indonesia mengalami peningkatan dari tahun ke tahun. Berdasarkan data dari Kementerian Komunikasi dan Informatika tahun 2019, pengguna internet aktif Indonesia mencapai 150 juta dimana rentang usia 19-34 tahun mendominasi (Junawan \& Laugu, 2020). Peningkatan jumlah pengguna internet dan media sosial di Indonesia tidak dibarengi dengan kemampuan pengguna dalam memilah konten mana yang benar dan yang hoaks. Metode dan pola komunikasi di masyarakat juga mengalami perubahan. Pola komunikasi dari one-to-one audience atau oneto-many audience ke pola many-to-many atau few-to few dimana komunikasi terjadi secara bolak balik dengan broadcaster seperti yang terjadi di sosial media (Mustika, 2018). Komunikasi yang terjadi di sosial media ataupun secara langsung di 
masyarakat dikatakan efektif apabila komunikasi tersebut "berhasil". Komunikasi yang berhasil bila pesan diterima secara utuh (tepat seperti yang diharapkan ketika pesan itu disiapkan), dipahami, dan ditanggapi dengan jelas, seperti yang dimaksudkan oleh komunikator (Lumentut et al., 2017).

Di masa pandemi saat ini terdapat banyak konten hoaks terkait COVID-19 tersebar di masyarakat yang menyesatkan dan meresahkan. Hoaks merupakan informasi palsu, berita bohong atau fakta yang direkayasa (Juditha, 2018). Penyebaran berita palsu dapat menggiring opini publik dan membentuk persepsi yang menguji kecerdasan dan kecermatan pengguna. Konten hoaks disebarkan dengan tujuan sebagai bahan lelucon, menjatuhkan pesaing, promosi dengan penipuan, serta ajakan untuk melakukan sesuatu yang belum jelas manfaatnya (Rahadi, 2017). Oleh karena itu, hoaks dapat menimbulkan kepanikan publik, menjadi sarana penipuan, serta sebagai pengalihan isu (Mustika, 2018). Hoaks yang paling sering tersebar di media soal adalah informasi tentang kesehatan (Juditha, 2019).

Berdasarkan hasil pemantauan Kementerian Komunikasi dan Informatika Republik Indonesia, hoaks terkait COVID-19 hingga periode Mei 2020 tercatat sebanyak 1.401 konten hoaks yang beredar dimasyarakat (Yusuf, 2020). Dari jumlah tersebut media sosial facebook menjadi platform terbanyak yang memuat konten hoaks, yaitu sebanyak 999 konten dan telah ditindaklanjuti sebanyak 759 konten, serta selebihnya masih dalam proses tindak lanjut. Menurut Rahadi (2017), konten hoaks terdiri dari: berita bohong (fake news), tautan jebakan (clickbait), bias konfirmasi (confirmation bias), satire, posttruth, dan propaganda. Berdasarkan Kementerian Komunikasi dan Informatika Republik Indonesia (2019), beberapa ciri hoaks di media sosial diantaranya adalah sumber informasi dengan identitas yang tidak jelas, berisi pesan dan informasi yang membuat cemas dan panik, berisi pesan yang tidak mengandung $5 \mathrm{~W}+1 \mathrm{H}$, dan pihak yang menyebarluaskan informasi meminta informasi tersebut disebarluaskan semasif mungkin. Berbagai upaya dilakukan oleh pemerintah dalam menanggulangi penyebaran berita hoaks di masyarakat yaitu dengan melakukan pemblokiran situs internet yang dinilai sebagai sumber berita bohong dan bekerjasama dengan facebook dimana penggunanya dapat secara langsung melaporkan berita yang dianggap hoaks dan facebook akan meneruskannya ke fact-checker (Siswoko, 2017). Berdasarkan Stanley et al. (2021), penolakan masyarakat terhadap informasi COVID-19 yang disampaikan oleh petugas kesehatan dapat diatasi dengan memberi penjelasan penyebab pandemi yang lebih mendalam dan informasi yang dapat diakses oleh masyarakat. Tiga indikator untuk menilai kemampuan individu dalam memilah informasi yang bersifat hoaks (Mujahiddin \& Harahap, 2017). Pertama, kemampuan dalam menyaring judul yang provokatif, konten hoaks seringkali mencantumkan judul yang sensasional dan provokatif. Kedua, kemampuan mencermati alamat situs, sumber informasi yang bersifat hoaks juga berasal dari alamat situs yang belum terverifikasi sebagai situs resmi suatu instansi. Ketiga, kemampuan dalam memeriksa fakta pada konten, konten informasi pada berita hoaks tidak secara jelas mencantumkan darimana asal informasi, siapa narasumbernya dan apakah informasi tersebut dari lembaga yang dapat dipercaya. Oleh karena itu, yang menjadi prioritas penyadaran masyarakat terhadap hoaks ditujukan bagi remaja sebagai kelompok pengguna terbesar media sosial (Ningrum, 2019).

Karang taruna sebagai wadah bagi pemuda untuk mengembangkan diri, bertumbuh dan berkembang dengan dasar kesadaran serta tanggung jawab sosial dari, untuk, dan oleh pemuda yang berorientasi pada tercapainya kesejahteraan sosial bagi masyarakat (Andini et al., 2021). Pemuda Karang taruna diharapkan dapat menanggulangi permasalahan sosial yang dihadapi dengan berperan aktif dalam meningkatkan kesadaran dan kewaspadaan masyarakat khususnya terkait informasi hoaks COVID-19 yang tersebar. Oleh karena itu, melalui kegiatan pemberdayaan ini pemuda karang taruna sebagai konsumen aktif internet diharapkan dapat meningkatkan kemampuan untuk berpikir kritis dalam menyaring dan menafsirkan informasi yang diterima dari internet dan berperan aktif menangkal hoaks terkait COVID-19 di masyarakat. Karang Taruna Desa Bunga-Bunga merupakan perkumpulan pemuda di Desa Bunga-Bunga dengan jumlah anggota sebanyak 20 pemuda dari latar belakang pendidikan dan minat yang berbeda-beda. Letak Desa Bunga-Bunga berada di perbatasan Kecamatan Matakali dan Anreapi yang berjarak kurang lebih $45 \mathrm{Km}$ dari Universitas Sulawesi Barat. Akses internet di desa telah tersedia sehingga masyarakat dapat dengan mudah untuk memperoleh informasi baik melalui media sosial seperti Facebook, dan WhatsApp. Namun informasi yang tersebar di media sosial tidak semua merupakan informasi yang benar, akurat dan terpercaya. Pada akhir Maret lalu, kegaduhan dan keresahan masyarakat Desa Bunga-Bunga 
sempat terjadi yang disebabkan oleh informasi hoaks yang tersebar di sosial media Facebook dan WhatsApp. Informasi tersebut menyatakan bahwa terdapat "bayi berbicara meminta untuk makan telur rebus tengah malam agar terhindar dari virus korona". Saat ini juga terdapat beberapa warga masyarakat di desa yang percaya terhadap isu hoaks yang beredar bahwa "Virus corona adalah konspirasi dokter dan pemerintah daerah". Hoaks tersebut menyebabkan kondisi menjadi tidak kondusif yang dapat menimbulkan konflik di masyarakat.

Berdasarkan hal tersebut, permasalahan mendasar yang dimiliki oleh mitra adalah kemampuan yang terbatas dalam memilah informasi COVID-19 yang bersifat hoaks terutama yang bersumber dari internet. Permasalahan prioritas yang telah disepakati yaitu kebutuhan pemuda karang taruna akan adanya kegiatan yang dapat meningkatkan kemampuan komunikasi dan berpikir kritis pemuda terhadap informasi COVID-19 yang bersumber dari internet, khususnya dalam memilah judul artikel yang provokatif, mencermati alamat situs, dan memeriksa fakta pada konten informasi, serta teknik komunikasi efektif sehingga pemuda dapat berperan aktif dalam menangkal hoaks yang tersebar di Desa Bunga-Bunga.

\section{METODE}

Kegiatan pengabdian kepada masyarakat dilaksanakan pada bulan September-November tahun 2020. Peserta kegiatan ini adalah anggota karang taruna Desa Bunga-Bunga sebanyak 14 pemuda. Rangkaian kegiatan pengabdian terdiri dari tiga tahap. Tahap persiapan meliputi melakukan pertemuan dengan pihak Desa Bunga-Bunga untuk memastikan kegiatan pengabdian kepada pemuda karang taruna dapat dilaksanakan, menyepakati tata cara dan waktu pelaksanaan kegiatan, kegiatan pengabdian dilaksanakan di balai desa dengan memperhatikan protokol kesehatan COVID-19, dan menentukan metode kegiatan pengabdian, yaitu dengan ceramah dan diskusi. Selanjutnya tahap pelaksanaan meliputi peserta melakukan registrasi dan mengisi kuesioner pre-test, memberikan penyuluhan dengan topik komunikasi efektif, serta hoaks dan COVID-19 pada pemuda yang menjadi sasaran kegiatan ini. Selanjutnya melakukan diskusi dan tanya jawab terkait materi yang disampaikan. Tahap evaluasi diantaranya mengevaluasi pengetahuan pemuda terkait materi yang disampaikan dan pengisian kuesioner post-test. Pre-test dan post-test yang diberikan terdiri dari 10 item soal yang menilai pengetahuan tentang komunikasi efektif dan 10 item soal yang menilai pengetahuan tentang hoaks dan COVID-19.

\section{HASIL DAN PEMBAHASAN}

Kegiatan pengabdian masyarakat yang dilakukan di Desa Bunga-bunga Kecamatan Matakali Kabupaten Polewali Mandar diikuti oleh 14 orang anggota karang taruna dilaksanakan di aula Kantor Desa Bunga-Bunga. Kegiatan yang dilakukan adalah penyuluhan mengenai komunikasi dan hoaks terkaitCOVID-19. Dalam kegiatan penyuluhan, tim didampingi oleh Kepala Desa dan Ketua Karang Taruna. Hasil dari pre-test dan post test mengenai tingkat pengetahuan anggota karang taruna mengenai komunikasi dan hoaks COVID-19 dijabarkan pada Tabel I:

Tabel I. Hasil uji Wilcoxon terkait pengetahuan anggota karang taruna mengenai komunikasi

\begin{tabular}{|c|c|c|c|c|c|c|}
\hline \multirow{3}{*}{ No } & \multirow{3}{*}{ Kategori } & \multicolumn{4}{|c|}{ Tingkat Pengetahuan } & \multirow{2}{*}{ Uji Wilcoxon } \\
\hline & & \multicolumn{2}{|c|}{ Kurang Baik } & \multicolumn{2}{|c|}{ Baik } & \\
\hline & & $\mathrm{n}$ & $\%$ & $\mathbf{n}$ & $\%$ & Asymp.sig (2-tailed) \\
\hline 1 & Pre Test & 0 & 0 & 14 & 100 & \\
\hline 2 & Post Test & 1 & 7,1 & 13 & 92,9 & 0,058 \\
\hline
\end{tabular}

Berdasarkan Tabel I diketahui terjadi penurunan pengetahuan dari baik ke kurang baik. Data tersebut terdistribusi tidak normal, maka digunakan uji Wilcoxon untuk mengetahui apakah ada perbedaan tingkat pengetahuan sebelum dan setelah penyuluhan. Hasil uji Wilcoxon menunjukkan bahwa nilai Asymp.sig (2-tailed) 0,058 ( $p>0,005)$, sehingga dapat disimpulkan tidak terdapat perbedaan tingkat pengetahuan sebelum dan setelah dilakukan penyuluhan. Pemberian materi tentang komunikasi membahas tentang model komunikasi, metode komunikasi dan teknik komunikasi efektif. Penelitian Mustika (2018) menyatakan bahwa perilaku berkomunikasi secara santun, jujur dan tidak merugikan orang lain dapat 
menghindarkan diri dari tindakan menyebarkan ataupun memberikan informasi hoaks sehingga hal tersebut dapat menangkal hoaks ketika menerima pesan.

Tabel II. Hasil uji Paired Sample t-test terkait pengetahuan anggota karang taruna mengenai hoaks dan COVID-19

\begin{tabular}{|c|c|c|c|c|c|c|}
\hline \multirow{3}{*}{ No } & \multirow{3}{*}{ Kategori } & \multicolumn{4}{|c|}{ Tingkat Pengetahuan } & \multirow{3}{*}{$\begin{array}{c}\text { Uji Paired Sample t-test } \\
\text { Asymp.sig (2-tailed) }\end{array}$} \\
\hline & & \multicolumn{2}{|c|}{ Kurang Baik } & \multicolumn{2}{|c|}{ Baik } & \\
\hline & & $\mathbf{n}$ & $\%$ & $\mathbf{n}$ & $\%$ & \\
\hline 1 & Pre Test & 5 & 35,7 & 9 & 64,3 & 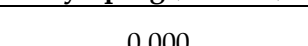 \\
\hline 2 & Post Test & 6 & 42,9 & 8 & 57,1 & 0,000 \\
\hline
\end{tabular}

Berdasarkan Tabel II diketahui terjadi penurunan pengetahuan dari baik ke kurang baik, karena data tersebut berdistribusi normal maka digunakan uji Paired Sample t-test untuk mengetahui apakah ada perbedaan tingkat pengetahuan sebelum dan setelah penyuluhan. Hasil uji menunjukkan bahwa nilai.sig (2-tailed) $0,000(p<0,005)$ sehingga dapat disimpulkan terdapat perbedaan tingkat pengetahuan sebelum dan setelah dilakukan penyuluhan. Pemberian materi tentang hoaks dan COVID-19 menjelaskan tentang jenis, dan ciri-ciri konten hoaks, cara memilah konten hoaks, dan beberapa contoh konten hoaks terkait COVID-19. Menurut Juditha, (2019) hoaks di bidang kesehatan lebih berbahaya dari jenis konten hoaks di bidang lain karena tidak hanya meresahkan tetapi dapat mengancam jiwa seseorang. Oleh karenanya, untuk mengantisipasi penyebaran hoaks di masyarakat perlu disertai dengan peningkatan literasi informasi oleh masyarakat sebagai pengendali utama arus penyebaran informasi. Dokumentasi kegiatan disajikan pada Gambar 1 sampai 3:

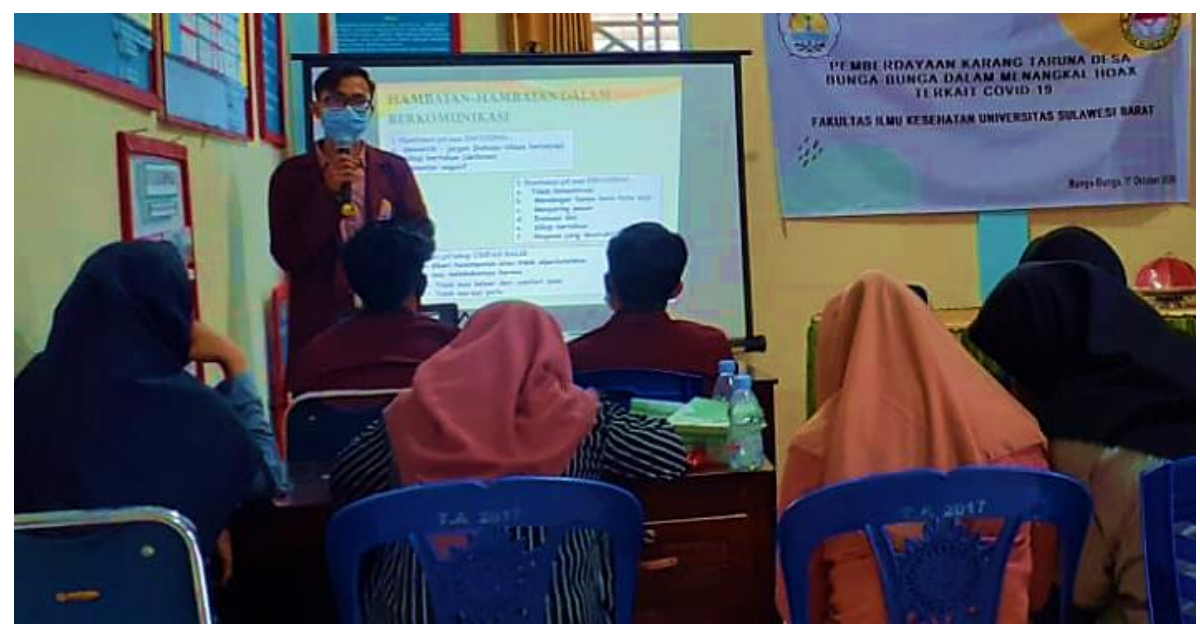

Gambar 1. Pemberian materi komunikasi efektif

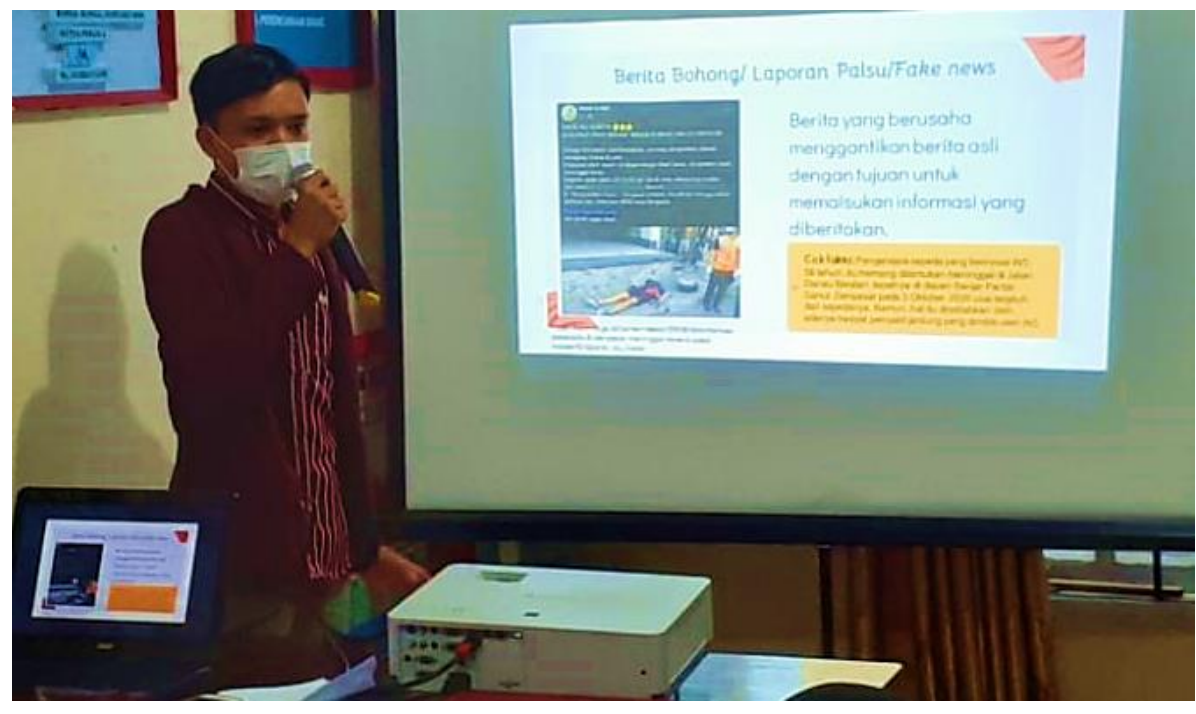

Gambar 2. Pemberian materi Hoaks dan COVID-19 


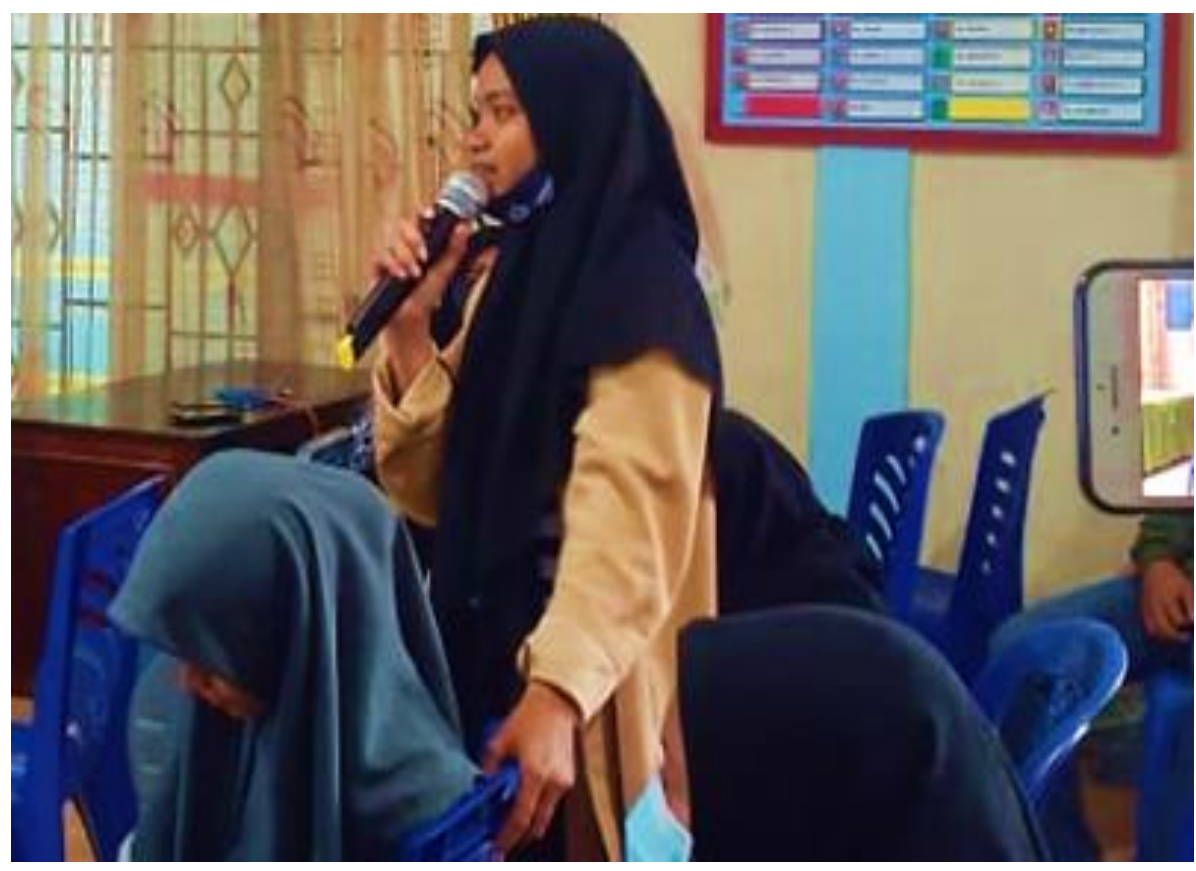

Gambar 3. Diskusi dan tanya jawab

Evaluasi sebelum dilaksanakan penyuluhan materi komunikasi, terkait dengan tingkat pengetahuan peserta saat sebelum penyuluhan dilakukan pre-test, maka diketahui bahwa tingkat pengetahuan berkategori baik sebesar 100\%, kemudian pada penyuluhan materi hoaks dan COVID-19, yang memiliki pengetahuan baik 64,3\% dan kurang baik 35,7\%. Evaluasi setelah dilaksanakan penyuluhan pada materi komunikasi, terkait dengan tingkat pengetahuan peserta setelah penyuluhan dilakukan post-test, maka diketahui bahwa tingkat pengetahuan berkategori baik sebesar 92,9\% dan pengetahuan kurang baik sebesar 7,1\%. Kemudian pada materi hoaks dan COVID-19, yang memiliki pengetahuan baik yaitu $57,1 \%$ dan kurang baik sebanyak 42,9\%. Berdasarkan hasil analisis, diketahui bahwa hasil uji Wilcoxon menunjukkan bahwa nilai Asymp.sig (2-tailed) 0,058 ( $\mathrm{p}>0,005)$ sehingga dapat disimpulkan bahwa tidak terdapat perbedaan tingkat pengetahuan sebelum dan setelah dilakukan penyuluhan pada materi komunikasi. Kemudian hasil uji Paired Sample t-test menunjukkan bahwa nilai Asymp.sig (2-tailed) 0,000 ( $\mathrm{p}<0,005)$ sehingga dapat disimpulkan bahwa terdapat perbedaan tingkat pengetahuan sebelum dan setelah dilakukan penyuluhan pada materi Hoaks COVID-19.

\section{KESIMPULAN}

Pemberdayaan pemuda merupakan salah satu hal yang penting dilaksanakan di era pandemi ini yang penuh dengan ketidakpastian. Melalui penyuluhan yang telah diberikan terkait komunikasi efektif, serta hoaks dan COVID-19 diharapkan agar pemuda Karang Taruna Desa Bunga-Bunga lebih termotivasi dan berperan serta aktif di masyarakat dalam menangkal hoaks terkait COVID-19. Berdasarkan hasil evaluasi kegiatan penyuluhan yang telah dilaksanakan, maka luaran dari kegiatan ini adalah: terdapat peningkatan pengetahuan peserta pada materi hoaks COVID-19 dan penurunan pengetahuan pada materi komunikasi, peserta dapat memilah informasi terkait hoaks COVID-19 yang terjadi saat ini, peserta dalam hal ini anggota karang taruna dapat menjadi pemberi informasi kepada masyarakat lain khususnya mengenai hoaks COVID-19 yang terjadi.

\section{UCAPAN TERIMA KASIH}

Ucapan terimakasih kepada Kepala Desa dan Karang Taruna Desa Bunga-Bunga atas partisipasi dan kerjasamanya dalam kegiatan pengabdian ini. 


\section{REFERENSI}

Andini, Y., Fauzia, N.S., Aprilia, N.A., Sari, R.E., Rodiah, S., Prabowo, B. 2021. Pentingnya Peran Pemuda-Pemudi Karang Taruna dalam Membantu Masyarakat Sekitar agar Patuh terhadap Protokol Kesehatan di Masa Pandemi Covid19 pada Karang Taruna Pemuda Pancasila KembanganSelatan. Jurnal Imiah Swara MaNajemen (Swara Mahasiswa Manajemen). 1(1):10-21.

Juditha, C. 2019. Literasi Informasi Melawan Hoaks Bidang Kesehatan di Komunitas Online. Jurnal Ilmu Komunikasi. 16(1):77-90. http://dx.doi.org/10.24002/jik.v16i1.1857

Juditha, C. 2018. Hoax Communication Interactivity inSocial Media and Anticipation (Interaksi Komunikasi Hoax di Media Sosial serta Antisipasinya). Jurnal Pekommas. 3(1):31-44. http://dx.doi.org/10.30818/jpkm.2018.2030104

Junawan, H., Laugu, N. 2020. Eksistensi Media Sosial, Youtube, Instagram dan Whatsapp Ditengah Pandemi Covid-19 Dikalangan Masyarakat Virtual Indonesia. Baitul 'Ulum: Jurnal Ilmu Perpustakaan dan Informasi. 4(1):41-57. https://doi.org/10.30631/baitululum.v4i1.46

Kementerian Komunikasi dan Informatika Republik Indonesia. 2019. Ini Cara Mudah Kenali Hoaks di Media Sosial! https://www.kominfo.go.id/content/detail/15941/ini-cara-mudah-kenali-hoaks-di-mediasosial/0/berita_satker

Lumentut, G.F., Pantow, J.T., Waleleng, G.J. 2017. Pola Komunikasi Pemimpin Organisasi dalam Meningkatkan Motivasi Kerja Anggota di LPM (Lembaga Pers Mahasiswa) Inovasi UNSRAT. Acta Diurna Komunikasi. 6(1):1-15

Mujahiddin, Harahap, M.S. 2017. Model Penggunaan Media Sosial. Jurnal Interaksi : Jurnal Ilmu Komunikasi. 1(2):142-155. http://dx.doi.org/10.30596/interaksi.v1i2.1200

Mustika, R. 2018. Etika Berkomunikasi Di Media Online Dalam Menangkal Hoax. Diakom : Jurnal Media dan Komunikasi. 1(2):43-50. https://doi.org/10.17933/diakom.v1i2.30

Ningrum, D.P. 2019. Pemanfaatan Media Sosial terhadap Fenomena "Hoax" di Kalangan Remaja Milenial (Studi di SMAN 1, Kecamatan Pleret, Bantul, Yogyakarta). Jurnal Ilmiah Padma Sri Kreshna. 1(1):23-33. https://doi.org/10.37631/psk.v1i1.35

Rahadi, D.R. 2017. Perilaku Pengguna Dan Informasi Hoax Di Media Sosial. Jurnal Manajemen dan Kewirausahaan. 5(1):5870. https://doi.org/10.26905/jmdk.v5i1.1342

Siswoko, K.H. 2017. Kebijakan Pemerintah Menangkal Penyebaran Berita Palsu atau "Hoax". Jurnal Muara Ilmu Sosial, Humaniora, dan Seni. 1(1):13-19. http://dx.doi.org/10.24912/jmishumsen.v1i1.330

Stanley, M.L., Barr, N., Peters, K., Seli, P. 2021. Analytic-thinking predicts hoax beliefs and helping behaviors in response to the COVID-19 pandemic. Thinking and Reasoning. 27(3):464-477. https://doi.org/10.1080/13546783.2020.1813806

Yusuf. 2020. Kominfo Temukan 1.401 Sebaran Isu Hoaks terkait Covid-19. https://aptika.kominfo.go.id/2020/05/kominfotemukan-1-401-sebaran-isu-hoaks-terkait-covid-19/ 